\title{
PARENTAL INVOLVEMENT PADA ORANG TUA DENGAN ANAK SLOW LEARNER DI BANDUNG
}

\author{
Marissa Putri Lutfiatin ${ }^{1}$, Stephani Raihana Hamdan² \\ 1,2Fakultas Psikologi, Universitas Islam Bandung, Jl. Tamansari No. 1 Bandung 40116. e-mail: \\ marissaputri05@gmail.com
}

\section{ABSTRACT: PARENTAL INVOLVEMENT ON PARENTS OF SLOW LEARNER CHILDREN IN BANDUNG}

Slow learner is one of students' characteristics that need special treatment in inclusive schools. The condition of children who are slow to learn has a high enough risk to stay in class. Therefore, the factor of parental involvement in student learning is important for slow learner children's education. The purpose of this research is to give description on how the parental involvement in SDN X. This is a descriptive research with 42 people as population. As a measurement we use Self Assessment of School / Program Parent Involvement Practices Based on Joyce Epstein's Six Type of Involvement. The result of this research show that $69,05 \%$ has a low parental involvement and learning at home aspect has the lowest percentage about $59,52 \%$. Based on these results, it is necessary to increase the involvement of parents with slow learner children, especially in repeating material at home so that the learning achievement of slow learner students can be achieved optimally.

\section{Keywords: Inclusive Education, Slow Learner, Parental involvement.}

Slow learner merupakan salah satu karakteristik siswa yang perlu mendapatkan penanganan khusus di sekolah inklusi. Kondisi anak yang lambat belajar mempunyai resiko cukup tinggi untuk tinggal kelas. Oleh karenanya faktor keterlibatan orang tua dalam pembelajaran siswa menjadi penting bagi pendidikan anak slow learner. Tujuan dari penelitian ini adalah untuk melihat gambaran mengenai parental involvement pada orang tua dengan anak slow learner pada SDN X. Penelitian ini merupakan penelitian deskriptif dengan populasi sebanyak 42 orang. Alat ukur yang digunakan dalam penelitian ini berupa kuesioner Self Assessment of School / Program Parent Involvement Practices berdasarkan teori Joyce Epstein (2001). Hasil penelitian menunjukkan bahwa parental involvement di SDN X termasuk rendah dengan persentase sebesar $69,05 \%$ dan aspek yang memiliki persentase tertinggi adalah aspek learning at home dengan persentase sebesar $59,52 \%$. Berdasarkan hasil ini maka perlu adanya upaya peningkatan keterlibatan orang tua dengan anak slow learner khususnya dalam pengulangan materi di rumah agar prestasi belajar siswa slow learner dapat tercapai optimal.

\section{Kata Kunci: Pendidikan Inklusi, Slow Learner, Parental Involvement}

\section{PENDAHULUAN}

Pada era milenial ini pendidikan menjadi program wajib yang di canangkan oleh pemerintah secara gratis dan hal tersebut berlaku bagi siapapun warga Negara Indonesia yang memenuhi kriteria untuk program wajib belajar 9 tahun dan bukan hanya anak yang tergolong normal atau sehat secara psikis dan fisiologis namun diberikan juga kepada anak yang berkebutuhan khusus (Maulipaksi, 2017).

Sistem pendidikan ini bersifat inklusi yaitu sistem penyelenggaraan pendidikan yang memberikan kesempatan kepada semua peserta didik termasuk siswa yang memiliki kelainan dan 
PARENTAL INVOLVEMENT PADA ORANG TUA DENGAN ANAK SLOW LEARNER DI BANDUNG

memiliki potensi kecerdasan dan/atau bakat istimewa untuk mengikuti pendidikan atau pembelajaran dalam lingkungan pendidikan secara bersama-sama dengan peserta didik pada umumnya sesuai dengan amanat Permendiknas Nomor 70 Tahun 2009 Tentang Pendidikan Inklusi. Sekolah inklusi kini alternative bagi anak berkebutuhan khusus untuk mendapatkan pelayanan pendidikan (Garnida, 2015).

Adapun kondisi pendidikan inklusi di Indonesia masih menghadapi banyak kendala misalnya fasilitas yang kurang memadai untuk penyelenggaraan inklusi, kurangnya pengetahuan dan keterampilan guru mengajar siswa berkebutuhan khusus, masalah kurikulum dan kebijakan yang belum sesuai dengan kondisi lapangan (Tarnoto, 2016; Pratiwi, 2016; Supriyanto, 2019)

Kota Bandung sendiri telah di tetapkan menjadi kota pendidikan inklusi pada tahun 2013. Pemerintah Kota Bandung telah memberikan bantuan berupa dana, pendidik, fasilitas yang memang di perlukan bagi terlaksananya pendidikan inklusi. Sejak tahun 2015, Ridwan Kamil selaku walikota saat itu menerapkan kebijakan yang menyatakan seluruh sekolah di Bandung wajib menerima siswa tanpa memandang kemampuan siswa, sehingga siswa berkebutuhan khusus wajib diterima di sekolah reguler.
Dalam pelaksanaan pendidikan inklusi salah satu karakteristik siswa berkebutuhan khusus yang ditemui adalah siswa lamban belajar (slow learner) yang memiliki resiko cukup tinggi untuk tidak naik kelas. Siswa slow learner memiliki beberapa ciri yaitu kemampuan dibawah ratarata kelas, prestasi belajar selalu di bawah KKM, selalu terlambat dalam pengumpulan tugas, daya tangkap materi rendah, dalam memahami materi butuh pengulangan, dan senang berteman dengan anak yang usianya dibawahnya (Hadits, 2006; Widyastono, 2007 Ishartiwi, 2010. Pramudiana, 2017).

Selama ini focus keberhasilan pendidikan inklusi lebih menyoroti lembaga dan juga pendidik, dalam arti kata guru (Supriyanto, 2019; Amor, Mayumi, Karrie, Thompson, Verdugo, Burke \& Aguayo, 2019; Stanley, Grimbeek, Bryer, \& Beamish, 2021, Kart\& Kart, 2021).

Salah satu faktor yang belum banyak diteliti adalah keterlibatan orang tua dalam pendidikan inklusi padahal hal ini merupakan salah satu faktor suksesnya atau berkembanganya seorang anak baik dalam segi akademik maupun kemampuan anak dalam pendidikan inklusi (Retnaningtya, 2017; Stanley Grimbeek, Bryer, \& Beamish, 2021). Orang tua juga berperan untuk meningkatkan kemampuan anak, karena dari orang tualah pertama kali anak akan dibentuk dan kemudian pihak sekolah akan membantu mengarahkan sesuai dengan kemampuan yang kemudian di kembangakan (Balli, 2016).

Marissa Putri Lutfiatin, Fakultas Psikologi Universitas Islam Bandung. Email: marissaputri05@gmail.com Stephani Raihana Hamdan, Fakultas Psikologi Universitas Islam Bandung. Email: stephanihamdan@unisba.ac.id 
PARENTAL INVOLVEMENT PADA ORANG TUA DENGAN ANAK SLOW LEARNER DI BANDUNG

Maka dari itu keterlibatan orang tua dalam pendidikan inklusi akan membantu dalam mengetahui arah pendidikan sekolah, metode yang digunakan, dan merasa lebih dekat. Menurut paparan dari Balli (2016) menyatakan bahwa keikutsertaan orang tua dalam pendidikan inklusi dan mengikuti proses pendidikan anaknya merupakan suatu hal yang sangat berharga, namun beberapa sekolah tidak mengikut sertakan orang tua dan orang tua merasa bahwa mereka tidak diberikan informasi yang cukup mengenai perkembangan anaknya di sekolah.

Keterlibatan orang tua dianggap penting dalam proses pendidikan, namun kenyataan di lapangan di temukan bahwa terdapat lembaga pendidikan yang menemukan hambatan dalam melakukan komunikasi antar sekolah dan orang tua. Selain itu masih kurang terbukanya sistem pendidikan sekolah menjadikan terhambatnya keterlibatan orang tua dalam pendidikan di sekolah (Syamsuddha \& Dion, 2017)

Selain itu peran serta orang tua dalam pendidikan di sekolah dapat membantu pihak sekolah untuk memahami dan mengetahui kekuatan setiap anak. Jika sekolah dapat melakukan relasi yang baik maka akan banyak informasi yang di dapat dari anak didik tersebut, kemudian orang tua dan pihak sekolah bisa menjadi rekan untuk mengefektifkan pendidikan terhadap pelajar. (MacKichan \& Harkins, 2013). Oleh karena itulah penelitian ini bertujuan meneliti keterlibatan orang tua dalam pendidikan inklusi di sekolah.

\section{METODE}

Penelitian ini menggunakan metode studi deskriptif yang menggambarkan keterlibatan orang tua siswa sekolah dasar di Bandung (Arikunto, 2010). Dalam penelitian ini populasi adalah orang tua siswa yang memiliki kebutuhan khusus slow learner yang bersekolah di SD berdana bantuan operasional sekolah dan wajib menyelenggarakan pendidikan inklusi. Sampel penelitian diperoleh melalui metode convenience sampling mengacu pada pengambilan sampel dengan mendapatkan orang atau unit yang tersedia dengan mudah (Silalahi \& Atif, 2015). Dalam rentang waktu pengambilan data diperoleh sampel penelitian sejumlah 42 orang, yaitu 15 orang ayah dan 27 orang ibu. Teknik pengumpulan data menggunakan kuesioner dan wawancara.

Kuesioner di susun sendiri oleh peneliti dengan mengadaptasi Self Assessment of School / Program Parent involvement Practices berdasarkan enam bentuk keterlibatan orang tua (Parent Involvement) yang dikemukakan oleh Epstein (2001). Kuesioner menggunakan skala Likert, berjumlah 16 item dan telah diuji validitas melalui expert judgment dan nilai uji reliabilitas a $=0,916$ yang menyatakan valid reliable dan masuk ke dalam realibilitas sangat tinggi menurut tingkat reliabilitas Guildford (Sudaryono, 2017).

Marissa Putri Lutfiatin, Fakultas Psikologi Universitas Islam Bandung. Email: marissaputri05@gmail.com Stephani Raihana Hamdan, Fakultas Psikologi Universitas Islam Bandung. Email: stephanihamdan@unisba.ac.id 
PARENTAL INVOLVEMENT PADA ORANG TUA DENGAN ANAK SLOW LEARNER DI BANDUNG

Epstein mengungkapkan terdapat enam

bentuk keterlibatan dengan orangtua yaitu: parenting, komunikasi, volunteer, melibatkan orangtua dalam pembelajaran anak di rumah, pengambilan keputusan, dan kolaborasi dengan kelompok masyarakat (Coleman, 2013).

Parental Involvement menunjukkan bagaimana orang tua ikut berinteraksi dengan pihak sekolah dalam kegiatan sehari-hari atau kegiatan lain yang dilakukan oleh anak. Berikut aspek dari parent involvement yaitu:

a. Parenting

Keterlibatan orang tua yang ditunjukkan dalam bentuk dukungan orang tua membangun lingkungan rumah/keluarga untuk mendukung anak-anak sebagai siswa. Contoh keterlibatan orang tua adalah mengantar atau menjemput anaknya berangkat ke sekolah dari rumah, atau orang tua ikut membantu anak dalam belajar.

\section{b. Communicating}

Keterlibatan berupa bentuk komunikasi pihak orang tua dan sekolah yang efektif tentang program sekolah dan kemajuan belajar anak. Contohnya orang tua dan pihak sekolah terutama guru wali saling memiliki kontak atau nomor telepon satu sama lain, orang tua hadir dalam ketika dipanggil oleh pihak sekolah, orang tua berkomunikasi baik dengan bertatapan secara langsung maupun lewat alat komunikasi.

c. Relawan/Volunteering

Keterlibatan orang tua dalam program sukarelawan sekolah. Contohnya orang tua ikut mempersiapkan anaknya untuk tampil ketika sekolah mengadakan pentas seni, ikut menyumbang dalam bentuk dana ketika mengadakan kegiatan studi tour sekolah.

d. Learning at Home

Keterlibatan orang tua dalam pembelajaran anak di rumah. Adanya keterlibatan baik bersifat informasi dan ide kepada anggota keluarga di rumah tentang bagaimana membantu siswa belajar di rumah dengan pekerjaan rumah. Contohnya orang tua ikut membantu anak ketika belajar, ikut menemani anak ketika belajar, menyediakan referensi seperti buku di rumah.

e. Decision Making

Keterlibatan orang tua dalam pengambilan keputusan pembelajaran anak di sekolah. Contohnya orang tua berdiskusi dengan wali kelas ketika ada perubahan strategi belajar, pengambilan keputusan untuk remedial/kursus tambahan atau diskusi mengenai adanya guru pendamping.

\section{f. Collaborating with Community}

Keterlibatan orang tua dalam berbagai sumber daya dan layanan dari masyarakat untuk memperkuat program sekolah, pembelajaran dan pengembangan siswa. Contohnya orang tua terlibat pada kegiatan ekstrakulikuler anak di luar sekolah, orang tua mengarahkan anak mengikuti kegiatan sesuai minat dan bakat anak, memfasilitasi anak dengan mentor atau guru les di luar sekolah.

Marissa Putri Lutfiatin, Fakultas Psikologi Universitas Islam Bandung. Email: marissaputri05@gmail.com Stephani Raihana Hamdan, Fakultas Psikologi Universitas Islam Bandung. Email: stephanihamdan@unisba.ac.id 


\section{PARENTAL INVOLVEMENT PADA ORANG TUA DENGAN ANAK SLOW LEARNER DI BANDUNG}

Untuk wawancara dilakukan dengan mengacu pada daftar pertanyaan wawancara yang diturunkan berdasarkan aspek keterlibatan orang tua dari teori Epstein (2001).

Dalam pelaksanaan pengambilan data peneliti sebelumnya memberikan angket pada pihak sekolah dasar inklusi untuk memberikan daftar nama siswa lamban belajar di tiap sekolah dan kemudian peneliti menghubungi orang tua siswa dari daftar tersebut. Kuesioner dibagikan hanya pada orang tua yang bersedia mengikuti penelitian dan memiliki anak sesuai kriteria siswa berkebutuhan khusus lamban belajar. Orang tua mengisi kuesioner secara daring melalui survey online maupun pengisian langsung didampingi peneliti. Setelah mengisi, orang tua juga diberikan wawancara untuk menggali mengenai keterlibatan mereka dalam pendidikan anaknya.

\section{HASIL}

Tabel 1

Distribusi Frekuensi Parent Involvement

\begin{tabular}{lcc}
\hline \multicolumn{1}{c}{ Kategori } & $\mathrm{F}$ & $\mathrm{P}$ \\
\hline Rendah & 29 & $69.05 \%$ \\
Tinggi & 13 & $30.95 \%$ \\
Total & 42 & $100 \%$ \\
\hline
\end{tabular}

Berdasarkan hasil perhitungan di tabel 1 diketahui bahwa parental involvement pada sekolah dasar inklusi tergolong rendah dengan persentase sebesar $69,05 \%$ dengan responden sebanyak 29 orang dan sebanyak 13 orang dengan persentase 30,95\% memiliki parent involvement yang tinggi.

Tabel 2

Aspek Keterlibatan Orang Tua

\begin{tabular}{cccccc}
\hline Aspek & Tinggi & \multicolumn{2}{c}{ Rendah } \\
& F & $\%$ & F & $\%$ \\
\hline Parenting & 4 & 9,52 & 38 & 90,48 \\
Communicating & 14 & 21,42 & 28 & 78,58 \\
Volunteering & 8 & 19,04 & 34 & 80,96 \\
Learning At Home & 25 & 59,52 & 17 & 40,48 \\
Decision Making & 14 & 33,33 & 28 & 66,67 \\
Collaborating With Community & 12 & 28,57 & 30 & 71,43 \\
\hline
\end{tabular}

Berdasarkan hasil pengolahan data pada tabel 2 dapat diketahui bahwa dalam aspek keterlibatan orang tua, menunjukkan bahwa bahwa aspek parenting menunjukkan aspek terendah, yaitu 90,48\% dari total responden masih memiliki keterlibatan parenting yang rendah. Sedangkan aspek keterlibatan orang

Marissa Putri Lutfiatin, Fakultas Psikologi Universitas Islam Bandung. Email: marissaputri05@gmail.com Stephani Raihana Hamdan, Fakultas Psikologi Universitas Islam Bandung. Email: stephanihamdan@unisba.ac.id 
PARENTAL INVOLVEMENT PADA ORANG TUA DENGAN ANAK SLOW LEARNER DI BANDUNG

tua tinggi terbanyak adalah aspek pembelajaran di rumah (learning at home) khususnya dalam item membantu anak mengerjakan tugas sekolah, sebanyak $59,52 \%$ berada pada tingkat keterlibatan tinggi

Tabel 3

Gender dan Parent Involvement

\begin{tabular}{ccccc}
\hline & \multicolumn{2}{c}{ Parental Involvement Rendah } & \multicolumn{2}{c}{ Parental Involvement Tinggi } \\
\cline { 2 - 5 } & $\mathrm{F}$ & $\%$ & $\mathrm{~F}$ & $\%$ \\
\hline Ayah & 12 & 80 & 3 & 20 \\
Ibu & 17 & 63 & 10 & 37 \\
\hline
\end{tabular}

Berdasarkan peran orang tua, pada tabel 3 menunjukkan bahwa $80 \%$ ayah memiliki keterlibatan yang rendah. Sedangkan $63 \%$ ibu memiliki keterlibatan yang juga rendah. Dengan kata lain, secara umum keterlibatan orang tua, baik ayah maupun ibu belum optimal.

\section{DISKUSI}

Berdasarkan hasil perhitungan di tabel 1 diketahui bahwa parental involvement pada sekolah dasar inklusi pada sebagian besar orang tua masih tergolong rendah. Hal ini menunjukkan bahwa keterlibatan orang tua dengan anak slow leaner belum optimal dan masih perlu ditingkatkan.

Berdasarkan hasil pengolahan data pada tabel 2 dapat diketahui bahwa dalam aspek parental involvement, sebagian besar orang tua menunjukkan keterlibatan tinggi pada aspek belajar di rumah dan masih rendah keterlibatannya dalam aspek parenting. Lebih lanjut berdasarkan peran orang tua, pada tabel 3 menunjukkan bahwa baik ayah atau ibu masih menunjukkan keterlibatan yang rendah. Meski demikian data menunjukkan bahwa keterlibatan ayah lebih rendah jika dibandingkan keterlibatan ibu dalam pembelajaran anaknya yang slow learner.

Dalam aspek parenting yang merupakan aspek terendah, dari hasil wawancara menunjukkan bahwa umumnya orang tua mengalami kebingungan dalam membantu anaknya yang memang membutuhkan pengulangan berkali-kali dalam proses belajar sehingga mereka merasa kewalahan. Mereka merasa kondisi anak slow learner menyebabkan mereka cenderung kurang melibatkan diri dalam mendukung anaknya meningkatkan prestasi di sekolah. Orang tua menyatakan adanya upaya "menerima" bahwa anaknya lamban belajar, sehingga tidak memerlukan upaya lebih karena dipandang tidak mungkin berprestasi di sekolah. Kondisi ini mendorong orang tua tidak memfasilitasi anak mereka menjadi seorang siswa berprestasi di sekolahnya. Selain itu banyak dari orang tua belum memahami

Marissa Putri Lutfiatin, Fakultas Psikologi Universitas Islam Bandung. Email: marissaputri05@gmail.com

Stephani Raihana Hamdan, Fakultas Psikologi Universitas Islam Bandung. Email: stephanihamdan@unisba.ac.id 
PARENTAL INVOLVEMENT PADA ORANG TUA DENGAN ANAK SLOW LEARNER DI BANDUNG

seberapa penting parenting yang baik dan akan berpengaruh terhadap anak - anak mereka (Fitriyani, 2015).

Dalam aspek komunikasi orang tua untuk terlibat langsung dengan anak masih rendah. Hal tersebut terlihat dari persentase orang tua yang terlibat dalam komunikasi dengan pihak sekolah yaitu sebesar $21,42 \%$.

Menurut Epstein (2001) ada hal yang harus dipahami dari aspek communicating oleh orang tua yaitu orang tua dapat memahami program dan kebijakan sekolah, pemantauan dan informasi akan perkembangan anak, menanggapi masalah siswa secara efektif, interaksi dengan guru dan kemudahan komunikasi dengan sekolah dan guru. Orang tua belum memahami secara jelas apa pentingnya komunikasi dengan pihak sekolah dengan mengetahui perkembangan dan hambatan yang dialami oleh anak mereka. Sebagian besar dari mereka hanya akan berkomunikasi dengan pihak sekolah apabila diberi undangan atau sekolah mengadakan perkumpulan dengan orang tua siswa. Selain itu komunikasi intens hanya terjadi apabila saat pembagian raport akhir tahun saja. Orang tua jarang melakukan pertemuan informal untuk sekedar menanyakan apa yang terjadi pada anak mereka sebagai siswa sekolah tersebut.

Pada aspek volunteering, sebanyak 80,96\% orang tua kurang memperhatikan keterlibatan pada program sekolah yang memerlukan sukarelawan orang tua. Kebanyakan orang tua anak slow learner pasif dan jarang terlibat dengan kegiatan komite orang tua. Sesuai dengan yang dikemukakan oleh Epstein (2001) bahwa pada aspek volunteering orang tua diharapkan dapat memahami pekerjaan guru, meningkatkan kenyamanan di sekolah, dan pelaksanaan kegiatan sekolahdi rumah. Dimana orang tua juga diharapkan membantu pihak sekolah untuk ikut membantu melancarkan dan mensukseskan program pembelajaran yang sudah dijalankan oleh pihak sekolah. Namun kondisi orang tua yang kurang terlibat volunteering menjadi kendala untuk meningkatkan pembelajaran anak.

Sebesar $59,52 \%$ orang tua siswa sudah memahami bahwa pendidikan bukan hanya dilakukan di sekolah tetapi keterlibatan orang tua di rumah dirasa sangat penting untuk menunjang pendidikan siswa. Epstein (2001) menyatakan bahwa pada aspek ini orang tua diharapkan dapat mengetahui bagaimana cara mendukung, mendorong, dan membantu siswa di rumah setiap tahun. Namun berdasarkan wawancara menunjukkan adanya kesulitan orang tua dalam membantu anaknya belajar karena orang tua tersebut cenderung menuruti apa yang diminta oleh anaknya. Anak slow learner sering menyatakan kurang paham jika dijelaskan materi oleh orang tua dan lebih memilih untuk meminta bantuan guru sekolahnya. Kondisi membuat anak slow learner kurang optimal belajar di

Marissa Putri Lutfiatin, Fakultas Psikologi Universitas Islam Bandung. Email: marissaputri05@gmail.com

Stephani Raihana Hamdan, Fakultas Psikologi Universitas Islam Bandung. Email: stephanihamdan@unisba.ac.id 
PARENTAL INVOLVEMENT PADA ORANG TUA DENGAN ANAK SLOW LEARNER DI BANDUNG

rumah. Padahal pembelajaran siswa slow learner memerlukan pengulangan dan seharusnya hal ini dilakukan di rumah.

Dalam aspek decision making, jumlah keterlibatan orang tu dalam berdiskusi dengan sekolah mengenai pekerjaan kelas dan pekerjaan rumah menunjukkan keterlibatan rendah yang cukup banyak sebesar $66,67 \%$. Hal ini menunjukkan upaya keterlibatan orang tua dalam mengambil keputusan terkait pembelajaran anaknya masih belum sepenuhnya terlibat dengan pihak sekolah. Dalam wawancara, orang tua menyatakan bahwa mereka lebih menyerahkan keputusan apapun pada pihak sekolah. Mereka merasa yakin pihak sekolah yang lebih mengerti dan merasa tidak perlu memahami program pengajaran setiap tahun dan tentang apa yang dipelajari anak di masing-masing subjek pelajaran.

Dalam aspek collaboration with community, orang tua yang belum memahami tentang seberapa pentingnya mengetahui kelebihan dan mengarahkan anaknya dengan hal lain diluar bidang pendidikan sebanyak $71,43 \%$. Orang tua masih berfokus pada bahwa anak yang pintar adalah anak yang secara akademik selalu baik tanpa melihat kelebihan lain yang dimiliki anak. Selain itu belum ada upaya dari orang tua untuk bekerjasama dengan pihak lain yang dapat membantu anak mengetahui cara belajar lain yang dirasa cocok dan nyaman sehingga anak lebih mudah memahami materi. Umumnya orang tua menilai anaknya cukup mendapat pembelajaran di sekolah saja.

Dalam kaitannya dengan peran orang tua, data penelitian menunjukkan jumlah ayah yang terlibat dalam pembelajaran anak slow learner masih rendah sebesar $80 \%$. Umumnya para ayah menyatakan bahwa mereka tidak perlu terlibat langsung karena peran tersebut merupakan tanggung jawab istrinya di rumah. Para ayah juga menyatakan kesibukan bekerja di luar rumah menyebabkan waktu mereka sedikit dan menjadi hambatan untuk mendampingi anak belajar. $20 \%$ ayah yang memiliki keterlibatan dalam kategori tinggi menyatakan bahwa mereka ingin terlibat dengan pembelajaran anak karena mengetahui bahwa peran ayah penting dalam kehidupan anaknya. Umumnya mereka juga berprofesi sebagai wirausaha sehingga waktu kerja lebih fleksibel. Namun ada ayah yang bekerja sebagai pegawai kantoran dengan waktu kerja padat tetap memiliki keterlibatan tinggi karena upaya melibatkan diri dalam pembelajaran anak dapat dilakukan di luar waktu kerja, misalnya saat magrib atau malam hari sebelum anak tidur. Hal ini sejalan dengan pandangan Cabrera \&Tamis Le-Monda (2013) yang menyatakan bahwa masih perlu peningkatan kesadaran ayah untuk lebih terlibat dalam pengasuhan anak mereka.

Pada pihak Ibu, jumlah yang masuk pada kategori rendah masih cukup banyak yaitu $63 \%$. Umumnya para ibu mengeluhkan kesulitan mendampingi belajar anaknya yang slow learner.

Marissa Putri Lutfiatin, Fakultas Psikologi Universitas Islam Bandung. Email: marissaputri05@gmail.com Stephani Raihana Hamdan, Fakultas Psikologi Universitas Islam Bandung. Email: stephanihamdan@unisba.ac.id 
PARENTAL INVOLVEMENT PADA ORANG TUA DENGAN ANAK SLOW LEARNER DI BANDUNG

Cara belajar yang perlu berulang dan contoh yang konkrit sangat penting bagi anak slow learner (Sedyaningrum, 2002). Namun pemahaman strategi ini belum dipahami oleh orang tua. Beberapa ibu yang bekerja menyatakan alasan bahwa pekerjaan telah menyita waktu dan energinya. Saat pulang kerja, para ibu sudah lelah dan menyebabkan mereka kurang terlibat. Namun para ibu menyatakan bahwa mereka adalah pihak yang selalu berhubungan dengan pihak sekolah, termasuk yang hadir dalam pertemuan orang tua-guru dan hadir dalam pembagian raport. Para ibu rumah tangga menyatakan bahwa meski tidak bekerja, namun beban kerja di rumah juga tinggi terutama jika memiliki jumlah anak lebih dari satu atau memiliki anak bayi atau balita. Padahal keterlibatan kedua orang tua baik ayah maupun ibu merupakan faktor penting yang berperan sebagai pondasi keberhasilan anak di masa depan (McBride, Dyer, Liu, Brown, \& Hong, 2009).

\section{SIMPULAN DAN SARAN}

Berdasarkan hasil penelitian mengenai parental involvement dari anak slow learner di Bandung menunjukkan bahwa keterlibatan orang tua mayoritas termasuk kategori rendah dan masih perlu peningkatan di masa depan. Aspek keterlibatan learning at home merupakan keterlibatan yang memiliki persentase tertinggi dan aspek keterlibatan parenting merupakan keterlibatan yang memiliki persentase terendah paling rendah. Keterlibatan ayah lebih rendah dibandingkan dengan keterlibatan ibu, meski keterlibatan keduanya dalam pembelajaran anak slow learner masih perlu ditingkatkan.

Adapun saran yang diberikan berdasarkan hasil temuan adalah perlunya upaya sistematis untuk meningkatkan keterlibatan orang tua dengan pendidikan anak slow learner. Perlunya kegiatan yang dapat meningkatkan kesadaran orang tua mengenai pentingnya keterlibatan mereka dalam pembelajaran anak slow learner. Baiknya kegiatan seminar, workshop atau pelatihan yang dapat diikuti oleh orang tua agar ikut terlibat dalam kegiatan anak dilakukan bekerjasama dengan sekolah. Kegiatan seminar parenting perlu dilakukan dengan materi yang spesifik dilakukan pada orang tua dengan siswa berkebutuhan khusus sesuai dengan kondisi anak. Tips dan strategi pendampingan anak slow learner berbeda dengan parenting anak pada umumnya. Khususnya jika ditujukan pada siswa slow leaner yang memerlukan pengulangan dan contoh konkrit dalam pembelajarannya. Kegiatan juga dapat menyasar khusus pada peningkatan keterlibatan peran ayah yang perlu dibedakan dengan peran ibu sehingga kedua peran ini dapat terlibat secara maksimal dengan pembelajaran anaknya.

Peningkatan keterlibatan orang tua dalam pembelajaran anak juga dapat dilakukan

Marissa Putri Lutfiatin, Fakultas Psikologi Universitas Islam Bandung. Email: marissaputri05@gmail.com

Stephani Raihana Hamdan, Fakultas Psikologi Universitas Islam Bandung. Email: stephanihamdan@unisba.ac.id 
dengan membuat kegiatan diskusi orang tua dan pihak sekolah yang lebih intensif diluar waktu pembagian raport. Pendekatan guru wali yang informal juga perlu dilakukan dengan memperhatikan latar belakang orang tua dan kondisi siswa. Peran komite sekolah perlu lebih dioptimalkan guna menjadi jembatan orang tua dan sekolah.

$$
\text { Bagi penelitian selanjutnya, }
$$
direkomendasikan untuk menggali penerimaan orang tua dengan anak slow learner. Penerimaan bukan berarti pasrah dengan keadaan anak, melainkan perlu memaksimalkan upaya pendampingan anak. Selain itu penelitian mengenai keterlibatan orang tua di luar setting sekolah (kolaborasi) masih perlu dikembangkan. Penelitian selanjutnya juga dapat mengeksplorasi bagaimana peran pengasuhan ayah dan ibu bagi anak berkebutuhan khusus, khususnya dalam kondisi sosial budaya Indonesia.

\section{DAFTAR PUSTAKA}

Amor, AM, Mayumi $H$, Karrie A. S, JR. Thompson, MA, Verdugo, KM. Burke \& Aguayo, V (2019) International perspectives and trends in research on inclusive education: a systematic review, International Journal of Inclusive Education, 23:12, 12771295 , DOI: $0.1080 / 13603116.2018 .1445304$

Arikunto, S. (2010). Metode peneltian. Jakarta: Rineka Cipta.
Balli, D. (2016). Importance of Parental Involvement to Meet the Special Needs of their Children with Disabilities in Regular Schools. Academic Journal of Interdisciplinary Studies MCSER Publishing, RomeItaly. Vol 5 No 1.

Cabrera, N. J., \& Tamis-LeMonda, C. S. (Eds.). (2013). Handbook of father involvement: Multidisciplinary perspectives. Routledge.

Coleman, J.S. (2013). Parental involvement in education. US Department of Education, Office of Educational Research and Improvement, Programs for the Improvement of Practice.

Epstein, JL. (2001). School, Family and Community, Partnerships: Your Handbook for Action (2nd edition).

Fitriyani, L. (2015). Peran Pola Asuh Orang Tua Dalam Mengembangkan Kecerdasan Emosi Anak. Lentera, Vol. XVIII, No. 1, Juni 2015.

Garnida, D. (2015). Pengantar Pendidikan Inklusif. Bandung : Refika Aditama.

Hadits, A. (2006) Pendidikan Anak Berkebutuhan Khusus. Bandung: Alfabeta.

Ishartiwi. (2010). Implementasi Pendidikan Inklusif Bagi Anak Berkebutuhan Khusus.

M, A.; Kart, M. (2021). Academic and Social Effects of Inclusion on Students without Disabilities: A Review of the Literature. Educ. Sci. 2021, 11, 16. DOI : 10.3390/educsci11010016

Marissa Putri Lutfiatin, Fakultas Psikologi Universitas Islam Bandung. Email: marissaputri05@gmail.com Stephani Raihana Hamdan, Fakultas Psikologi Universitas Islam Bandung. Email: stephanihamdan@unisba.ac.id 
MacKichan, M. D., \& Harkins, M. J. (2013). Inclusive education: Perceptions of parents of children with special needs of the individual program planning process. Electronic Journal for Inclusive Education, 3(1), 7.

Maulipaksi, D. (2017). Sekolah Inklusi dan Pembangunan SLB Dukung Pendidikan Inklusi.

McBride, B. A., Dyer, W. J., Liu, Y., Brown, G. L., \& Hong, S. (2009). The differential impact of early father and mother involvement on later student achievement. Journal of educational psychology, 101(2), 498.

Pramudiana, I. D. (2017) . Implementasi Kebijakan Pendidikan Inklusi Untuk $A B K$ di Surabaya. Jurnal Dimensi Penddikan dan Pembelajaran Vol 5 No 1.

Pratiwi, J. C. (2016). Sekolah inklusi untuk anak berkebutuhan khusus: tanggapan terhadap tantangan kedepannya. Prosiding Ilmu Pendidikan, 1(2).

Retnaningtya, M. S. (2014). keterlibatan orangtua dalam pendidikan anak di TK Anak Ceria (Doctoral dissertation, UNIVERSITAS AIRLANGGA).

Sudaryono. (2017) . Metodologi Penelitian. Depok : PT Raja Grafindo Persada

Sedyaningrum, S. (2002). Anak Slow Learner, Pemahaman dan Penanganannya, Jakarta: Rineka Cipta

Stanley, T., Grimbeek, P., Bryer, F., \& Beamish. (2021). Comparing Parents' Versus Teachers' Attitudes to Inclusion: When PATI meets TATI.
Silalahi, U., \& Atif, N. F. (2015). Metode Penelitian Sosial Kuantitatif. Bandung: Refika Aditama

Tarnoto, N. (2016). Permasalahanpermasalahan yang dihadapi sekolah penyelenggara pendidikan inklusi pada tingkat SD. Humanitas: Jurnal Psikologi Indonesia, 13(1), 50-61.

Syamsuddha, S. T, \& Dian G. (2017). Parental Involvement in Indonesia: A study on two Public Schools in Makassar. Advances in Social Science, Education and Humanities Research (ASSEHR), Volume 66

Widyastono, H. (2007). Penyelenggaraan Pendidikan Inklusi Bagi Anak Berkelainan. Jurnal Pendidikan dan Kebudayaan, No. 065, Tahun Ke-13.

Marissa Putri Lutfiatin, Fakultas Psikologi Universitas Islam Bandung. Email: marissaputri05@gmail.com Stephani Raihana Hamdan, Fakultas Psikologi Universitas Islam Bandung. Email: stephanihamdan@unisba.ac.id 